\title{
HEALTH RISK OF OCCUPATIONAL EXPOSURE IN WELDING PROCESSES I. GENOTOXIC RISK
}

\author{
Lenka Borská1, Zdeněk Fiala², Jindra Šmejkalová , Jaroslav Tejral
}

Charles University in Prague, Faculty of Medicine in Hradec Králové: Institute of Pathological Physiology ${ }^{1}$; Institute of Hygiene and Preventive Medicine ${ }^{2}$

Summary: The welding processes belong among the important sources of occupational pollutions. The welding fumes are ranked, according to the classification of IARC (International Agency for Research on Cancer), into the group of 2B. In our study we have performed the investigation of twenty men (exposed group) working in the stainless steel welding industrial processes ( 11 welders and 9 grinders, average age was 31 years, $55 \%$ of smokers, average time period of welding occupational exposure was 8 years $)$. The concentrations of chromium $\left(0.557-16.343 \mathrm{mg} / \mathrm{m}^{3}\right)$ and nickel $\left(0.340-10.129 \mathrm{mg} / \mathrm{m}^{3}\right)$ in occupational atmosphere highly exceeded established values of maximum permitted concentrations $\left(0.1 \mathrm{and} 1.0 \mathrm{mg} / \mathrm{m}^{3}\right.$, respectively). The concentrations of manganese did not exceed its permitted values. Total concentrations of 12 polycyclic aromatic hydrocarbons (PAH) in occupational atmosphere varied from 300.9 to $961.2 \mathrm{ng} / \mathrm{m}^{3}$. For purposes of biological monitoring, the levels of chromosomal aberrations were determined in the exposed and control group. Healthy blood donors servedas a control group. People from that group were not occupationally exposed to harmful chemical compounds ( 20 men, average age was 36 years, $40 \%$ of smokers). Increased level of chromosomal aberrations of exposed group brought the evidence about higher genotoxic risk of investigated welding processes.

Key words: Welding; Grinding; Occupational exposure; Health risk; Genotoxicity

\section{Introduction}

The technology of welding process belongs among the well-known pollutant sources of occupational environment $(7,12,25)$. Chromium, nickel and manganese belong among the most presented pollutants $(26,27,44)$. The hexavalent chromium and the compounds of nickel are ranked among the proven carcinogens for human (group 1 according to IARC). Metallic nickel is ranked into the group of substances with supposed carcinogenic effect to human (group $2 \mathrm{~A}$ according to IARC) (18). The degenerative changes of brain structure belong among the most serious toxic effect of manganese $(7,10,23,31)$. Hazardous are also pneumonitis with higher mortality $(7,23,31)$. Tejral et al. $(43,44)$ presented recurring findings of higher air concentration of polycyclic aromatic hydrocarbons (PAH) at welding processes. PAH represent the largest group of chemical carcinogens produced during burning, pyrolysis and pyrosynthesis of organic matter $(2,4,5,9,13,14,19)$.

Luster et al. (30) classify the PAH and the metals mentioned above as the xenobiotics which can cause the immunosuppression and which decrease the resistance of an organism against infection and tumor cells. In addition to described harmful chemical compounds, the ozone and nitrogen oxides are presented at welding processes, too.
Noise, vibrations and all kinds of non-ionizing radiation including UV radiation also belong among the risk physical factors at mentioned processes $(7,20,23,31)$. According to IARC, the welding fumes are classified into the group 2B as a possible humoral carcinogens (18). The aim of presented work is focused on the evaluation of genotoxic effects of occupational exposure at welding processes.

\section{Methods}

\section{Investigated groups}

For our study a group of 20 workers (men), occupationally exposed to welding fumes was chosen (11 welders, 9 grinders, average age was 31 years, $55 \%$ of smokers, average time period of welding occupational exposure was 8 years). The welding of stainless steel materials has been practiced by WIG method in protective atmosphere of argon. All exposed workers filled the questionnaire oriented to their personal history, occupational anamnesis and non-occupational activities. None of investigated workers has been exposed to harmful (genotoxic) chemical substances out of their work.

At the technologies of investigated industrial plant there was no possibility to select an adequate control group of non-exposed workers. Due to this fact the cytogenetic find- 
ings of the exposed group of workers were statistically compared with the findings in a group of healthy blood donors (man), marked as a control group (people of various types of occupations, living at the same locality as people from the exposed group). People from the control group were not occupationally exposed to harmful chemical compounds ( 20 men, average age was 36 years, $40 \%$ of smokers).

\section{Air analysis}

The ambient air samples of exposed welders and grinders were taken during their working shift. The air sample collections were executed by personal sampling apparatus SKC (Sampler Aircheck, type PCXR 224, USA) equipped by filters Synpor 4 (diameter $35 \mathrm{~mm}$ ). Nearly $70 \%$ of working time was covered by the ambient air monitoring. The concentrations of investigated metals (chromium, nickel, manganese) were determined by the atomic absorption spectrophotometry (AAS). The determination was executed according to the hygienic standard laboratory method (17).

The determination of PAH in occupational air was executed by the method of EPA TO-13 (13). Personal sampling apparatus, described above, collected the air samples. The sample analysis was performed by the high performance liquid chromatography (Hawlet Packard 1050) with the fluorescent detection. In each analyzed air sample the concentrations of 12 chosen PAH were determined (phenanthrene, anthracene, fluoranthene, pyrene, benz[a]anthracene, chrysene, benzo[b]fluoranthene, benzo[k]fluoranthene, benzo[a]pyrene, dibenz[a,h]anthracene, benzo[g,h,i]perylene and indeno[1,2,3-cd]pyrene). The total PAH concentrations were calculated as a sum of concentrations of 12 presented PAH.

\section{Chromosomal aberrations}

From all persons of exposed and control group the samples of non-coagulated venous blood were taken. The blood samples were analyzed by the standard method of cytogenetic analysis of peripheral lymphocyte (1).

\section{Statistical calculations}

For statistic evaluation of our results the "Sigma Stat System" by the Jandel Company (USA) was used. After the control over normality of the data (Kolmogorov-Smirnov test), t-test and non-parametric Mann-Whitney tests were used for the comparison of investigated groups. The statistical process includes the calculation of arithmetic means and standard deviations in particular subsets of analyzed parameters. In the next step, the signification of the differences between calculated means of the subsets was tested.

\section{Results}

\section{Air analysis}

The concentrations of chromium and nickel in occupational atmosphere of welders and grinders $(n=7)$ highly ex- ceeded the established values of their maximum permitted concentrations. The concentrations of manganese did not exceed its maximum permitted value (Tab. 1).

Total concentrations of $12 \mathrm{PAH}$ in occupational atmosphere of welders and grinders $(n=2)$ varied from 300.9 to $961.2 \mathrm{ng} / \mathrm{m}^{3}$ (Tab. 2). There was no feasibility to compare our results with some permitted values because the maximum permitted concentrations of total (sum) PAH have not been declared. The levels of carcinogenic benzo[a]pyrene were deep below the individual values of its maximum permitted concentrations for occupational environment (11).

Tab. 1: Toxic metals in the occupational atmosphere.

\begin{tabular}{|l|c|c|}
\hline Metals & $\begin{array}{c}\text { Range of concentrations } \\
\left(\mathrm{mg} / \mathrm{m}^{3}\right) \\
(\mathrm{n}=7)\end{array}$ & $\begin{array}{c}\text { NPK-P } \\
\left(\mathrm{mg} / \mathrm{m}^{3}\right)\end{array}$ \\
\hline Chromium & $0.557-16.343$ & 0.1 \\
\hline Nickel & $0.340-10.129$ & 1.0 \\
\hline Manganese & $0.040-1.384$ & 2.0 \\
\hline
\end{tabular}

$\mathrm{n}=$ number of analysis

NPK-P = maximum permitted concentrations (11)

Tab. 2: Polycyclic aromatic hydrocarbons (PAH) in the occupational atmosphere.

\begin{tabular}{|l|c|}
\hline PAH & $\begin{array}{c}\text { Range of concentrations } \\
\left(\mathrm{ng} / \mathrm{m}^{3}\right) \\
(\mathrm{n}=2)\end{array}$ \\
\hline Phenanthrene & $278.9-900.0$ \\
\hline Anthracene & $3.7-13.1$ \\
\hline Fluoranthene & $13.5-37.2$ \\
\hline Pyrene & $1.0-3.8$ \\
\hline Benz[a]anthracene & $2.1-3.5$ \\
\hline Chrysene & $1.7-2.9$ \\
\hline Bezo[b]fluoranthene & $1.0-1.1$ \\
\hline Bezo[k]fluoranthene & $<1$ \\
\hline Benzo[a]pyrene & $<1$ \\
\hline Dibenz[a.h]anthracene & $<1$ \\
\hline Benzo[g.h.i]perylene & $<1$ \\
\hline Indeno[1.2.3-cd]pyrene & $<1$ \\
\hline Sum of PAH & $300.9-961.3$ \\
\hline
\end{tabular}

$\mathrm{n}=$ number of analysis

\section{Cytogenetic analysis}

Twenty people from the exposed group and twenty from the control group were examined for chromosomal aberrations (Tab. 3). In each sample 100 mitotic sets were analyzed. In the exposed group of welders and grinders there were analyzed in a total 2000 cells. From this number, 54 cells $(2.70 \%)$ were aberrated. In 12 cases we found the structural aberrations (breaks and exchanges), in 41 cases the polyploidies (numerical aberrations) and one time the 
endoreduplication (so called "other type of aberrations"). In the control group there were analyzed 2000 cells. From this number 11 cells $(0.55 \%)$ were aberrated. The structural and numerical aberrations predominated. The statistic analysis revealed significantly higher level of aberrated chromosomes of peripheral lymphocytes in the group of welders and grinders.

Reference level of chromosomal aberrations for adults in Czech population $(n=20)$ has been declared in the range from 0 to $1.88 \%$ (1). Final value $2.70 \%$ of aberrated cells at exposed workers (Tab. 3) was found significantly higher when compared with the reference level $(\mathrm{p}<0.001)$.

Tab. 3: Chromosomal aberrations of peripheral lymphocytes.

\begin{tabular}{|cc|c|c|c|c|}
\hline \multirow{2}{*}{$\begin{array}{c}\text { Type of } \\
\text { aberration } \\
(\%)\end{array}$} & $\begin{array}{c}\text { Exposed } \\
\text { group } \\
(\mathrm{n}=20)\end{array}$ & $\begin{array}{c}\text { Control } \\
\text { group } \\
(\mathrm{n}=20)\end{array}$ & $\mathrm{p}-$ value & $\begin{array}{c}\text { Statistic } \\
\text { signifi- } \\
\text { cance }\end{array}$ \\
\hline $\mathrm{ABB}$ & $\begin{array}{l}\text { Mean } \\
\text { SD }\end{array}$ & 2.70 & 0.55 & 0.0000181 & $* * *$ \\
\cline { 3 - 7 } & 1.646 & 0.973 & & \\
\hline SAB & Mean & 0.60 & 0.15 & 0.03109 & $*$ \\
\cline { 3 - 7 } & SD & 0.583 & 0.654 & & \\
\hline NAB & Mean & 2.05 & 0.3 & 0.0000271 & $* * *$ \\
\cline { 3 - 6 } & SD & 1.532 & 0.458 & & \\
\hline JAB & Mean & 0.05 & 0.05 & 1 & NS \\
\cline { 3 - 6 } & SD & 0.218 & 0.218 & & \\
\hline
\end{tabular}

Mean $=$ arithmetic mean

$\mathrm{SD}=$ standard deviation

$\mathrm{n}=$ number of analyzed subjects

$\mathrm{ABB}=$ aberrated cells

$\mathrm{SAB}=$ structurally aberrated cells

$\mathrm{NAB}=$ numerically aberrated cells

$\mathrm{JAB}=$ aberration of another type

$* * *=\mathrm{p}<0.001$

$*=\mathrm{p}<0.05$

$\mathrm{NS}=$ non significant

\section{Discussion}

Selected toxic metals (chromium, nickel and manganese) occurring in the occupational environment of welding manufactures, dispose of significant toxic potential including the carcinogenic potential $(8,15,35,36,41,42)$.

Beside the welding processes, an excessive exposure to chromium can be found also within manufacturing of alloys and during the galvanic metal coating (16.38). It is known that the toxicity of chromium and chrome compounds increases significantly during inhalation of aerosol particles. Welding fumes represent a typical example of aerosol mixture $(18,27,28,29,42,44)$. According to the scientific data, the welding fumes contain from 18 to $26 \%$ of chromium (mostly in a risk hexavalent form) when the work is executed in so-called inert atmosphere. Other types of working atmosphere contain 3-4\% of chromium (7).
For a long time the chromium concentrations in welding fumes were not taken as a health risk factor. Lautner et al. (28) measured the concentrations of chromium particles in the occupational atmosphere of stainless steel welders. The volume of these particles creates $1.9-12.3 \%$ of the total volume of welding fumes. At welding technologies of stainless steel, Edme et al. (12) found an average air level of total chromium $201 \mu \mathrm{g} / \mathrm{m}^{3}$. Karlsen et al. (21) described an average concentration of total chromium $120 \mu \mathrm{g} / \mathrm{m}^{3}$ and an average concentration of hexavalent chromium $21 \mu \mathrm{g} / \mathrm{m}^{3}$.

Many analyses of atmosphere of different workplaces (iron foundries, welding manufactures, battery manufactures) showed that the workers are exposed to nickel in a large range, varying from micrograms to milligrams per cubic meter of air $(6,7,21,22)$. In the occupational environment of welders, Karlsen et al. (21) determined an average nickel concentration $260 \mu \mathrm{g} / \mathrm{m}^{3}$. Very high short-term exposures to chromium and nickel at welding occupational atmosphere were described in the study of Tejral et al. (43). These exposures highly exceeded the maximum permitted concentrations. They varied from hundreds of micrograms to tens of milligrams per cubic meter for chromium and from hundreds of micrograms to units of milligrams per cubic meter for nickel.

As resulted from our findings, the levels of chromium and nickel occurred highly above the maximum permitted concentrations. The total chromium concentrations varied from 0.557 to $16.343 \mathrm{mg} / \mathrm{m}^{3}$, nickel concentrations from 0.340 to $10.129 \mathrm{mg} / \mathrm{m}^{3}$. Maximum permitted concentrations achieve the level of $0.1 \mathrm{mg} / \mathrm{m}^{3}$ for chromium and 1.0 $\mathrm{mg} / \mathrm{m}^{3}$ for nickel.

The occupational exposure to manganese occurs within metallurgy, electrical, glass making and chemical industry. The coal burning and the metallurgy can be designated as main sources of manganese emissions into the atmosphere (7). In the case of manganese exposure, the respiratory tract is assumed as the most important pathway of exposure. Karlsen et al. (21) found in the breathing zones of welders an average concentration of manganese about 14 $\mu \mathrm{g} / \mathrm{m}^{3}$. Tejral et al. (43) presented the findings of very high short-term exposures to manganese in occupational atmosphere of stainless steel welding. These values reached tens milligrams per cubic meter and highly exceeded the maximum permitted concentrations for manganese. All the results of manganese level in presented work were under the maximum permitted concentration $\left(2.0 \mathrm{mg} / \mathrm{m}^{3}\right)$. They varied from 0.040 to $1.384 \mathrm{mg} / \mathrm{m}^{3}$.

As it was indicated above, it is necessary to take into account the presence of PAH in occupational environment of welding manufactures $(13,32,34,43,44)$. At presented work, the range of PAH levels (300.9-961.2 ng/ $\mathrm{m}^{3}$ ) corresponded to our previous findings $(43,44)$. However, it must be noted that presented total PAH concentrations significantly exceeded the findings of other authors from machine-industry environment. For example, concentrations of total PAH which were found in the occupational atmo- 
sphere of cutting, dispersion hardening and pressing of the metals varied from 66.9 to $106.0 \mathrm{ng} / \mathrm{m}^{3}$ (3).

Increased levels of chromosomal aberrations indicate the presence of exposure to some genotoxic factor(s) $(37,40)$. Impaired chromosomes of somatic cells increase the risk of tumors and degenerative diseases in human population. In addition, impaired chromosomes affected negatively the functions of cell repair mechanisms and interfere with the process of apoptosis $(37,39,40,45)$.

The cytogenetic analysis of chromosomal aberrations of peripheral lymphocytes often serves as a biological marker of early genotoxic effects of chemical substances. Knudsen et al. (24) described increased levels of chromosomal aberrations of peripheral lymphocytes in workers exposed to high concentrations of chromium in welding atmosphere. Tejral et al. (43) presented higher levels of chromosomal aberrations in peripheral lymphocytes of stainless steel welders. Myslak et al. (33) confirmed the genotoxic effect of chromium and nickel in welding fumes by the test of sisters' chromatides exchange (SCE) in peripheral lymphocytes. In presented study we described significantly higher occurrence of chromosomal aberrations in the exposed group of welders and grinders. It has to be stressed that the workers were exposed to high concentrations of chromium and nickel from their working atmosphere.

\section{Conclusion}

The results of biological monitoring, presented by chromosomal aberrations of peripheral lymphocytes, confirmed higher health risk level for workers exposed to high concentrations of toxic metals and $\mathrm{PAH}$ in the atmosphere of welding and grinding processes.

\section{References}

1. AHEM. The methods of biological monitoring of genotoxic effects of environmental factors. Cytogenetic analysis of peripheral lymphocytes. Suppl. AHEM 20/89. Praha: SZÚ, 2000:27.

2. Angerer J, Mannschreck C, Gundel J. Biological monitoring and biochemical effect monitoring of exposure to polycyclic aromatic hydrocarbons. Int Arch Occup Environ Health 1997;70(6):365-77

3. Apostoli P, Cassano F, Clonfero E et al. The toxicology and prevention of the risk occupational exposure to polycyclic aromatic hydrocarbons. II. Toxicology. Exposure assessment. Environmental and biological monitoring. G Ital Med Lav Ergon 1997;19(4):137-51.

4. ATSDR. Toxicological profile for polycyclic aromatic hydrocarbons (PAHs) Update. Atlanta, Georgia: U.S. Department of Health and Human Services, Public Health Service, Agency for Toxic Substances and Disease Registry (ATS DR), 1993:430.

5. ATSDR. Toxicological profile for polycyclic aromatic hydrocarbons(PAHs) Update. Atlanta, Georgia: U.S. Department of Health and Human Services, Public Health Service, Agency for Toxic Substances and Disease Registry (ATS DR), 1995:470.

6. Barceloux DG. Nickel. J Tox-Clin Tox 1999;37(2):239-58.

7. Bencko V, Cikrt M, Lener J. The toxic metals in occupational and non occupational human environment. Praha: Grada, 1995:228.

8. Bláha K, Cikrt M. The principles of health risk assessment. Praha: SZÚ, 1996:63.

9. Boffetta P, Jourenkova N, Gustavsson P. Cancer risk from occupational and environmental exposure to polycyclic aromatic hydrocarbons. Cancer Causes Control 1997;8(3):444-72.

10. Cikrt M, Málek B. Occupational medicine. Part I. Occupational Hygiene. Praha: SZÚ, 1995:137-51.

11. Decree of the government. Decree of the government of Czech republic No. 178/2001 Coll. Praha: Ministerstvo zdravotnictví, 2001:3682-803.
12. Edme JL, Shirali P, Mereau M et al. Assessment of biological chromium among stainless steel and steel welders relation to welding processes. Int Arch Occup Environ Health 1997;70(4):237-42.

13. EPA. The determination of benzo[a]pyrene and other polynuclear aromatic hydrocarbons in ambient air using gas chromatography and high performance liquid chromatography analysis. EPA TO-13. Cincinnati, OH: Environmental Protection Agency, Office of Health and Environmental Assessment, Environmental Criteria and Assessment Office, 1988

14. Fiala Z, Borská L, Vyskočil A et al. Polycyclic aromatic hydrocarbons II. Toxic effects. Acta Med (Hradec Králové) Suppl 2000; 43(3):37-61.

15. Goyer RA, Cherian MG (Eds). Toxicology of metals. Bichemical aspects. Berlin, Heidelberg, New York, Tokyo, Hong Kong, Barcelona, Budapest: Springer-Verlag, 1995:467.

16. Hassmanová V, Vaněčková J, Boušová K. Professional disorders to chromium and its compounds. Acta Med (Hradec Králové) Suppl 2000;43(1):33-7.

17. HEM. Methodical guide of ČSR chief hygienist No. HEM-340.2-12.4.78. The analytical methods for determination of chemical pollutants in occupational air. Praha: Ministerstvo zdravotnictví, 1978:5-9.

18. IARC. IARC Monographs on the evaluation of the carcinogenic risk of chemicals to humans. Chromium, nickel and welding. Vol. 49, Lyon, France: World Health Organization, International Agency for Research on Cancer, 1990:648.

19. IARC. IARC Monographs on the evaluation of the carcinogenic risk of chemicals to humans. Polynuclear aromatic compounds. Part 1. Chemical, environmental and experimental data. Vol. 32., Lyon, France: Worl Health Organization, International Agency for Research on Cancer, 1983:237.

20. Jirák $Z$ et al. Occupational medicine. Part 3. Occupational hygiene in basic manufacturing processes. Civop-Centrum. Praha: Pragoline, 1996:144.

21. Karlsen JT, Torgrimsen T, Langard S. Exposure to hazardous aerosols during manual metal arc welding on nickel-rich alloys. Occup Hygiene 1996;3(5):307-10.

22. Kiilunen M. Occupational exposure to chromium and nickel in the 1980s, Finland Sci Total Environ 1997;20(1-2):91-101

23. Kneidlová M. Chemical factors. The handbook of prevention in medical practice $\mathrm{V}$. The prevention of adverse factors from occupational setting and work technologies. Praha: SZÚ, 1998:519-20.

24. Knudsen LE, Boisen T, Christensen JM et al. Biomonitoring of genotoxic exposure among stainless steel welders. Mutat Res 1992;279(2):129-43.

25. Korczynski RE. Occupational health concerns in the welding industry. Appl Occup Environ Hyg 2000;15(12):936-45.

26. Kosnáč L. Catalogue of factors in welding processes. Bratislava: Research welding institute, 1991;3:200.

27. Kučera J, Bencko V, Papáyová A et al. Monitoring of occupational exposure in manufacturing of stainless steel constructions. Part I: Chromium, manganese, molybdenum, nickel and vanadium in the workplace air of stainless steel welders. Centr Eur J Publ Hlth 2001;9(4):171-5.

28. Lautner GM, Carver JC, Konzen RB. Measurement of chromium VI and chromium III in stainless steel welding fumes with electron spectroscopy for chemical analysis and neutron activation analysis. Amer Ind Hyg Assoc J 1978;38(8):651-60.

29. Lubyanova JP, Novichenko NL. On factors of carcinogenic risk in welders working with steel. Lek Sprava 1995;0(1-2):88-91.

30. Luster MI. Immunotoxicology. Clinical consequences. Toxicol Ind Hlth 1996; 12(3-4):533-5.

31. Málek B. Physical factors. The handbook of prevention in medical practice V. The prevention of adverse factors from occupational setting and work technologies. Praha: SZÚ, 1998:513-5.

32. Muller P, Leece B, Raha D et al. Scientific criteria document for multimedia standards development polycyclic aromatic hydrocarbons (PAH). Hazard identification and dose-response assessment. Ontario: Ministry of Environment and Energy, Standards Development Branch, 1997:576.

33. Myslak M, Kosmider K. Kinetics of cell division in peripheral blood lymphocytes in stainless steel welders. Medicina Pracy 1997;48(3):261-4.

34. Research Triangle Institute. Toxicological profile for polycyclic aromatic hydrocarbons. U. S.: Department of Health and Human Services, Public Health Service, Agency for Toxic Substances and Disease Registry, 1995:457.

35. Research Triangle Institute. Toxicological profile for nickel. U. S.: Department of Health and Human Services, Public Health Service, Agency for Toxic Substances and Disease Registry, 1997:261

36. Research Triangle Institute. Toxicological profile for chromium. U. S.: Department of Health and Human Services, Public Health Service, Agency for Toxic Substances and Disease Registry, 1998:375.

37. Rőssner P, Šrám RJ, Bavorová $\mathrm{H}$ et al. Spontaneous level of chromosomal aberrations in peripheral blood lymphocytes of control individuals of the Czech Republic population. Toxicol Lett 1998;97(7):137-42.

38. Rudolf E. A review of toxic effects of chromium. Acta Med (Hradec Králové) Suppl 1998;41(1):55-67.

39. Senft V, Losan F, Tucek M. Cytogenetic analysis of chromosomal aberrations of peripheral lymphocytes in workers occupationally exposed to nickel. Mutat Res 1992;273(3):171-9.

40. Srb V, Červinka M. Genotoxic effects of xenobiotics. Biol Listy 1994;59(2): 144-8. 
41. SZÚ. The system of human health state monitoring in relationship with environment. Subsystem 1. Technical report of 1999. Praha: SZÚ, 2000:132.

42. Stridsklev IC, Hemmingsen B, Karlsen JT et al. Biologic monitoring of chromium and nickel among stainles welders using the manual metal arc method. Int Arch Occup Environ Health 1993;65(4):209-19.

43. Tejral J, Srb V, Šmejkalová J et al. The health state evaluation of selected professions. Voj Zdrav Listy 1997;67(7):142-6.

44. Tejral J, Fiala Z, Bencko V et al. The health state of persons occupationally exposed to chromium, nickel, manganese and polycyclic aromatic hydrcarbons. Acta Med (HradecKrálové) Suppl 1999;42(2):65-9.

45. Wu FY, Tsai FJ, Kuo HW et al. Cytogenetic study of workers exposed to chromium compound. Mutat Res 2000;464(2):289-96.

Submitted November 2002.

Accepted January 2003.

MUDr. Lenka Borská, Ph.D.,

Charles University in Prague,

Faculty of Medicine in Hradec Králové,

Institute of Pathological Physiology,

Šimkova 870, 50038 Hradec Králové,

Czech Republic.

e-mail: borka@lfhk.cuni.cz 